\title{
Quo Vadis, Preservation Education?
}

\section{A Study of Current Trends and Future Needs in Graduate Programs}

\author{
By Karen F. Gracy and Jean Ann Croft
}

This research study assesses preservation education provided by academic institutions in North America. Educators teaching preservation in graduate library and information science programs were surveyed about the type and number of courses offered, content of preservation coursework, faculty resources, future plans for curricula, fieldwork and internship opportunities in preservation, and postgraduate employment data. The investigators hypothesize that current preservation education within traditional library and archival studies programs does not provide adequate preparation in the areas of technical and managerial expertise to deal with the preservation of digital collections, audiovisual media, or visual materials. This paper reviews the literature pertinent to study of preservation education, describes the research methodology employed in designing and conducting the survey, presents the resulting data, and analyzes the trends revealed by the data in order to understand more fully the goals and objectives of preservation education during the last decade and to gauge future directions of the field. This paper concludes by presenting plans for further research, which will expand upon initial findings of this survey.

Tn the past twenty-five years, the field of preservation education has matured Isignificantly from the watershed year of 1981, when the Conservation Education Program in the School of Library Service at Columbia University was established as the first conservation program to focus exclusively on library and archival materials. Tremendous progress has been made since 1981 in integrating conservation and preservation issues into the curricula of library and information science (LIS) programs. By 1994, Cloonan estimated that approximately thirty library schools in North America offered coursework in preservation. ${ }^{1}$ This figure represented tremendous progress in the preservation education agenda, which, as articulated by Marcum in 1992, declared that the primary objective was to produce "a new generation of archivists and librarians who will enter the profession already understanding the centrality of preservation." ${ }^{2}$

In the ten years since Cloonan surveyed the preservation education landscape, the LIS community has witnessed many changes in preservation program goals and concerns. The first major transition was the increased emphasis placed on digital reformatting as a tool in preservation work, accompanied by steadily growing concerns about how electronic resources thus created would

be maintained. Digital preservation, a term not even common in 1992, entered

Karen F. Gracy (kgracy@pitt.edu) is Assistant Professor, School of Information Sciences, and Jean Ann Croft (jeanann@pitt.edu) is Preservation Librarian, University Library Services, University of Pittsburgh. 
the mainstream in the mid-1990s as the new crisis to be met and conquered, as the Web became integrated into the library and archival environments and produced increasing numbers of digitized and born-digital resources.

While the brittle books crisis had galvanized librarians, archivists, and conservators in the 1980s and 1990s to discover solutions to the slow fires (brittle paper) endangering paper-based library collections, the preservation community has yet to be given a magic bullet solution to the dilemmas of digital preservation. Whereas the preservation of paper-based media favors an object-based approach, preservation professionals who wish to preserve digital materials must focus on the information contained within electronic objects rather than the media upon which the information is recorded. Because digital objects require a complex environment of hardware and software for their information to be accessed, and because that environment is susceptible to obsolescence in an alarming short period of time, the physical and chemical stability of electronic recording media is of less importance than maintaining access to the information itself. Electronic information is enmeshed within a web of format specifications, encryption systems, and compression algorithms. Untangling information from this technical environment is not easy.

Digital preservation requires an entirely new skill set, involving the mastery of such concepts as:

- understanding the process of digitization; i.e., how the information contained within analog objects is affected by the transformation to digital form, and how one may judge the quality of that transformation;

- recognizing the need to represent information objects in an authentic manner through quality control and descriptive practices (metadata); and,

- learning how to ensure the longevity of large quantities of digital material through such strategies as copying, reformatting, migration, and emulation.

These digital competencies are complex enough to demand a separate course. The continuing education community has made attempts to address this gap by offering workshops in this area, but until recently its emphasis was primarily on transforming objects from analog to digital form rather than the maintenance of such material once digitized. One of the most well-known continuing education opportunities in digitization is the Northeast Document Conservation Center's (NEDCC) School for Scanning, which has been offered regularly since $1995 .^{3}$ The preservation needs of born-digital material, such as electronic records, are still rarely discussed within continuing education workshops. Several field service programs, including NEDCC, Southeast Library Information Network
(SOLINET), and Amigos, have begun to offer workshops in preserving digital objects; however, the preservation of borndigital electronic records is still somewhat neglected. An exception is the Society of American Archivist's workshop, "Archival Perspectives on Digital Preservation," offered regularly since 2002 at its national conference and through its traveling workshop series. Finally, instructors have been hampered by the lack of case studies in the preservation of digital material. To the frustration of many librarians and archivists, digital preservation exists largely in a theoretical realm for most institutions.

Another area of increasing concern for preservation administrators is the presence of what has been referred to as non-book materials in library and archival collections. This category encompasses everything from photographic images, architectural drawings, and maps, to audiovisual material such as records, cassettes, reel-to-reel tapes, motion pictures, and videotapes. In 2001, the Association of Research Libraries (ARL) reported that its members collectively held more than sixty-four million objects that could be classified as visual materials (including photographs, pictures, maps, prints, slides, charts, posters, cartoons, engravings, and other graphic arts). ${ }^{4}$ In a 2004 study on audio collections in academic libraries, Smith, Allen, and Allen reported that a majority of ARL libraries have collections of more than 100,000 recorded sound objects, while most Oberlin libraries (a consortium of seventy-five leading liberal arts colleges) have collections that number more than $50,000 .^{5}$ For moving images, similar collections in size and scope exist throughout United States research libraries and archives. $^{6}$

Many of these items warrant immediate attention, as the formats upon which they are recorded are becoming obsolete and machines to play them are becoming scarce. Preservation educators often find that they cannot provide sufficient coverage of the preservation issues and challenges of these non-book media. Although some specialized programs have emerged to address the training needs of preservationists in these areas (particularly in the area of moving image preservation), and several workshops have been offered at professional conferences and by regional preservation field service programs, many libraries and archives still do not have easy access to such expertise.

With the ever-increasing amount of knowledge being required of preservation professionals in the areas of electronic media, visual materials, sound recordings, and moving images, the syllabi of preservation courses are becoming more and more populated with topics that were covered only superficially ten to fifteen years ago. Yet teaching preservation courses is becoming more difficult, because of the growing number of topics demanding attention.

Given the gaps addressed above, this study hypothesizes that current preservation education within traditional 
library and archival studies programs does not provide adequate preparation in the areas of technical and managerial expertise to deal with the preservation of digital collections, audiovisual media, or visual materials. The investigators approached these problems as issues worthy of research, in order to document the current situation and place these issues on the national LIS educational agenda. Specifically, the investigators sought to address the following research questions:

1. What is the composition of the curricula at university-based degree programs and field service programs in preservation education? How has that curricula changed over the past decade?

2. How do educators plan to keep pace with new formats and technological advancements?

3. Do preservation educators provide students with the opportunity to put theory into practice? If so, how is this achieved?

4. What do preservation educators see as the key knowledge and values in preservation education? How are these values reflected in the curricula?

The following report summarizes the results of the research undertaken to find answers to these questions.

\section{Review of Relevant Literature}

Cloonan examined whether preservation as a field is declining. ${ }^{7}$ In 2001 , she noted that:

the loss of preservation programs in some Association of Research Libraries (ARL) libraries and schools of library and information studies suggest that the field is withering when it should be blossoming. . . . At the same time, there is a continuing recognition of the importance of preservation throughout archives, museums, and libraries. This broad spectrum of interest should assure that it does not wither. New modes of collaboration present many possibilities as to whither preservation might go. ${ }^{8}$

Cloonan's observations about the continuing importance of preservation provided the impetus for this study, which focuses on the current state and future directions of preservation education. This survey of the literature briefly documents how education in the preservation field has changed during the last fifteen years. It reflects trends and reveals how educational programs have adapted to address the issues and challenges introduced by technological and philosophical change. It also shows how these modifications have affected training in traditional preservation techniques for books, paper, audiovisual, and electronic media.

\section{The Value of Preservation Education in the Library and Archival Communities}

Outside of a few specialized programs in LIS schools, preservation education has developed somewhat unevenly in the library and archival communities. While archival educators have long stressed the importance of preservation and conservation within their curricula, archival practitioners do not appear to be as vocal about its centrality to the archive field as one might expect. The library arena experiences the reverse-library educators do not require preservation as part of their prospectus, but preservation professionals, particularly those working in academic library environments, actively promote continuing education efforts.

In 1989, the United Nations Educational, Scientific and Cultural Organization (UNESCO) supported research to ascertain training needs in preservation and conservation, and this study concluded that while the archives community deemed such courses as mandatory within their curricula, library educators often viewed preservation and conservation as a "comparative luxury." This assertion came as a surprise to many preservation professionals, as the library community first commanded the spotlight in the preservation movement and cultivated their efforts into a recognized discipline. The archival community always has made the responsibility to preserve a central part of its mission. One may theorize that the emphasis on preservation in archival education emanated from its particular challenges, such as the multiplicity of formats and paper degradation, which are regularly encountered by archivists as part of the archival appraisal and processing procedures. Meanwhile, libraries struggle with the "tendency to concentrate on the whole of a question and use pre-established formulas to reach a single solution." ${ }^{\prime 10}$ In addition, the variety of formats and media inherent to archival collections pose significant preservation challenges, which are compounded by the paucity of standards, treatments, and educational opportunities, especially for electronic records, visual materials, and audiovisual materials. ${ }^{11}$ Kaplan and Banks state, "It is ironic that archivists have watched librarians capture the 'preservation spotlight.' It makes good sense for archivists to take a leadership role in preservation, because of the need to preserve unique materials, and because preservation is, after all, an expressly stated part of the archival mission." 12 Perhaps leadership by those librarians who collaborated to create standards and selection criteria in hopes of devising a national plan for preserving brittle materials had the ultimate result of helping to affirm the value of preservation and conservation as a specialty within the library profession. Inconsistencies in preservation terminology between the library and archival 
communities have compounded the dissonance between these two professions. Much work has been done, and continues to be done, to establish consensus in the preservation philosophy and vocabulary across the allied disciplines. ${ }^{13}$

Despite the strong influence of many practitioners on the development of the preservation profession, preservation education still does not form part of the core curriculum for many library and information science programs. One theory that may explain the lack of integration of preservation into all LIS programs is that many academics view preservation more as a collection of practical information and skills rather than a discipline grounded in theoretical knowledge and research. These educators also may view preservation needs as being better served by continuing education providers, rather than within a graduate school curriculum. The researchers plan to explore this in greater depth in a subsequent paper.

\section{Audiovisual and Electronic Media}

During the early 1990s, concern grew, especially among archivists, about audiovisual material preservation and the necessary training to teach these specialized skills. Reminiscent of Banks and his work in establishing conservation as a graduate-level study, audiovisual archivists have contended that training and education should occur in institutions of higher education, as workshops and seminars cannot adequately convey the theoretical knowledge, technical expertise, or scientific methods needed for certain jobs. ${ }^{14}$ The lack of international standards and practices, as well as the lack of agreement on a core body of knowledge to guide the development of curricula, further compound the challenges in training audiovisual archivists and librarians. ${ }^{15}$ With the establishment of the Association of Moving Image Archivists (AMIA) in 1991, these concerns coalesced into an international movement to foster graduate-level programs in moving image archiving and preservation. In the United States, the Library of Congress issued recommendations relating to film preservation that encouraged the moving image community to "create a systematic graduate program for educating new film preservation professionals and continuing education opportunities for those already in the field." ${ }^{.16}$ Within a decade, three programs in moving image archiving were established in the United States: the L. Jeffrey Selznick School of Film Preservation at the George Eastman House (1996), the Moving Image Archival Studies program at the University of California, Los Angeles (2002), and the Moving Image Archiving and Preservation program at New York University (2003). In 2002, the University of Pittsburgh also began to offer a concentration in moving image preservation through its Preservation Management program, which is a specialty within the School of Information Sciences' MLIS curriculum.
While the development of moving image preservation education has matured significantly in the last decade, formal training in audio preservation lags far behind. A smattering of course offerings may be found in LIS programs and as occasional workshops at conferences, such as the Society of American Archivists and the Association of Recorded Sound Collections; however, the need for trained professionals in this area remains unmet. Recent reports from the Council on Library and Information Resources (CLIR) indicate a need for more sound preservationists, but the sound-archiving community has not yet pushed to develop standalone graduate education programs. ${ }^{17}$

\section{Digital Dilemmas}

In the 1990s, preservation again captured the spotlight in the LIS community as libraries and archives began to focus on the potential power of digitization as a reformatting option and its great potential to enhance access to collections. ${ }^{18}$ Education in an information environment requires an understanding of digital and preservation resources, which will help provide insight for grappling with library services of the future. ${ }^{19}$

In an effort to rebrand themselves as "I-schools," many LIS programs have abandoned the word "library," removing it from their names and the degrees offered in an attempt to focus on "information science" or "information studies," promoting the emergence of new technologies and education into "the nature of information itself and its societal function." ${ }^{20}$ This development is a matter of some concern, as professional education serves to define and communicate the values of the profession. ${ }^{21}$ Unfortunately, this evolution seems to be happening at the expense of more traditional library offerings; courses teaching the "historical, technical, cultural and economic studies of the book and the methods of book production and supply, and the selection, arrangement, and storage of books in libraries" no longer constitute a primary component of the curricula. ${ }^{22}$ Accreditation and professional aspirations further impact conservation education, encouraging coursework concentrating on administration. ${ }^{23}$ As evidence of the lower status of preservation in many of these retooled programs, adjunct professors, rather than full-time faculty, are the most likely people to teach preservation courses, and preservation plays a limited role in the core curriculum of most programs. ${ }^{24}$ Another area of concern in preservation education is the lack of doctoral research undertaken in the preservation field resulting from the "predominantly practical approach to preservation." ${ }^{25}$

The change in emphasis from providing grounding in specific institutional practice and service to particular constituencies, to the mastery of the management of information, in all its myriad forms, has many implications for preservation education. The demands of traditional paper 
and document preservation must be balanced with the now-pressing concerns to preserve audiovisual and electronic media. These new imperatives should stimulate the development of the preservation curriculum and the hiring of full-time faculty to support such a curriculum, yet the current focus on information science and technology in LIS programs and the "withering field" to which Cloonan alludes suggest otherwise. ${ }^{26}$

The LIS field seems to be placing undue emphasis on the creation and distribution of digital resources, subverting the original concerns and drives of the preservation agenda. The key document that illustrates the tension between the old and new attitudes toward preservation is the recent ARL position paper Recognizing Digitization as a Preservation Reformatting Method. ${ }^{27}$ In this document, ARL put forth their endorsement of digitization as another preservation reformatting technique, outlining the benefits of digital technology and providing a list of best practices in the field.

The preservation field appears divided and conflicted when contemplating this topic. Adverse reactions to the ARL recommendations include concerns about economics and the level of commitment that digitization requires; hesitations in moving forward without concrete, universally accepted standards; comparisons of digitization projects specific for preservation purposes versus digitization for access and other purposes; and requests for more analysis from a risk perspective. ${ }^{28}$ At the same time, some leading preservationists commend ARL for taking these steps, and offer praise and support in encouraging the library community to engage proactively in the digitization process, "making sure that the creation of the virtual library will support the values of our profession and the value of the objects in our care." ${ }^{.29}$ Cunningham-Kruppa embraces the benefits that digital technology offers over microfilming, while Merrill-Oldham and Chapman view this call to action as an opportunity to make a concerted effort and commitment to promote standards and best practices. ${ }^{30}$ Although ARL clearly supports digitization as a preservation reformatting method, the association does not claim that it should be the only method employed in preservation. ${ }^{31}$ This debate highlights the centrality of digital preservation concerns in the field. As the library and archival professions grapple with preservation in the digital realm, education must keep students in the thick of the debate.

As the preservation community refocuses attention to new challenges and agendas, it builds upon the impressive foundation of those ground-breaking preservationists and educators of the first generation. These innovators inspired the authors of this article to study the more recent trends and concerns of preservation education, particularly as its curriculum continues to be rewritten to address the new imperative of electronic media preservation and more adequately deal with the concerns of audiovisual preser- vation. Thus, this research aims to thoroughly document current educational activities in the field of preservation and to give university and field service programs specific recommendations for directing educational endeavors into the next decade.

\section{Research Method}

This survey aims to analyze the extent of offerings found in formal library and information science degree programs and in continuing education sponsored by field service programs and other regional or local networks. Continuing education will be addressed in a subsequent paper. The survey also attempted to gauge preservation educators' attitudes and views across the spectrum of preservation education in relation to such topics as breadth and depth of curricula, current resources to support teaching of preservation, and growth of the field.

\section{Establishing a Working Population of Preservation Education Providers}

This assessment of preservation education was directed toward academic institutions in North America. Recipients of the graduate education survey were identified in several ways. Initially, the investigators relied upon the most recent list of schools accredited by the American Library Association. ${ }^{32}$ This group did not include those institutions offering conservation education offerings in museum studies programs or other cognate fields. To make sure that no potential recipients were overlooked, a general call for participation also was sent out via several electronic discussion lists: the Preservation Administration Discussion Group, or PADG; jESSE (a list devoted to discussion of library and information science education issues); and the Forum for Archival Educators (a private electronic discussion list whose members are educators in archival studies programs). ${ }^{33}$ The investigators also set up a Web site for individuals involved in preservation education to request a survey. ${ }^{34}$ Finally, an announcement was published in October 2003 issue of the Abbey Newsletter, a periodical devoted to current news and developments in library and archival preservation. ${ }^{35}$ When multiple responses were received from the same institution, the researchers compared responses and selected the most reliable.

To encourage participation, survey recipients were assured of the confidentiality of their responses. Because of this requirement, the investigators were sometimes required to aggregate data in order to maintain the confidentiality of participants despite the small size of the working population and the sample taken from it. 


\section{Development of the Survey Instrument and Analysis of Resulting Data}

The survey (see appendix) was sent to academic institutions, usually to the dean or director of master's programs, but also to course instructors themselves if they requested it. The investigators asked questions dealing with the following topics:

- type and number of courses offered;

- frequency of course offerings;

- enrollment statistics;

- presence or absence of preservation specialization as part of degree program;

- content of preservation coursework;

- incorporation of preservation into related coursework;

- faculty resources;

- future plans for curricula;

- fieldwork/internship opportunities in preservation; and

- postgraduate employment data.

To standardize coding and subsequent analysis of data, the surveys used checkboxes wherever possible, and refrained from open-ended questions as much as possible. Where participants were asked to fill in answers (for example, "list each preservation course offered"), the investigators created nominal coding categories to aggregate data.

To analyze the data, the investigators used a standard statistical analysis package, SPSS, for all survey data entry and analysis. The primary analysis used was frequency distribution; these data are presented in tabular form, with discussion accompanying each table.

\section{Potential Sources of Bias}

The investigators see several potential sources of bias in this research. First, the data may be slanted toward those individuals who are predisposed to participate in surveys. The response rate indicates that individuals from schools where preservation is actively supported were more likely to complete and return the survey than those from schools where preservation is infrequently or never taught.

Second, answers to certain questions about future plans in hiring and curriculum should be treated somewhat cautiously. Respondents who were not full-time employees of an institution or organization may not have had a complete understanding of the current situation vis-à-vis hiring or curriculum revision. Additionally, some institutions may be wary about revealing plans in this area (despite assurances of anonymity) for fear of being seen as making a firm commitment to the hire of new faculty or instructors or both, or offering new coursework.
The most significant potential bias of this research concerns truthfulness in reporting data. For the questions that asked respondents to provide hard numbers (such as enrollment figures for a five-year span, or the number of graduates who specialized in preservation during that same period), several participants indicated that the numbers that they were providing were estimates or guesses as they had not kept good records of such data. Thus the authors exercised extreme caution in interpreting these statistics, with the understanding that they may not be exact representations of the phenomenon being measured.

\section{Findings and Discussion}

In total, 64 surveys were sent to potential participants; this list consisted of educators identified through the initial compilation of the working population (as detailed above) as well as individuals who requested it via electronic mail. Recipients who did not respond to the call to participate were sent a reminder after six weeks; a second reminder was sent at twelve weeks after the initial contact to those who still had not responded. After three attempts at contact, the data collection period was considered closed.

The research team received a total of 43 completed surveys from academic institutions. This figure was reduced, however, due to the removal of duplicate responses; investigators accepted only one response from each school. Once duplicates were removed, 41 useable surveys remained. The response rate was calculated as 71.9 percent (numbers do not include surveys removed for the reasons noted above). This rate offers some reassurance that the investigators may rely on the results to be statistically accurate. The extremely small population size in question leads them to be very cautious, however, in interpreting results and their potential implications.

\section{Survey Responses}

Readers are invited to consult the appendix to examine the survey instrument; the report uses the abbreviation "Q" followed by the question number to indicate from which question the data are drawn (thus, Q1 refers to Question 1).

\section{Types of Courses and Frequency of Course Offerings}

Out of the 41 useable surveys, 32 of the respondents (78 percent) indicated that they offer coursework on preservation or conservation of library and archival materials, or both (Q1). This figure compares favorably to the figure cited by Cloonan in 1994, at which time she estimated that 30 schools offered one or more electives in preservation. ${ }^{36}$ Of 
those 32 schools currently offering preservation, however, almost 60 percent (19) offer only 1 course (usually an introductory survey course). Seven schools (21.9 percent) offer 2 courses, 4 schools (12.5 percent) offer 3 courses, and only 2 schools (6.3 percent) offer more than 3 courses (Q2).

Educators also were asked to list each preservation course offered at their institution, providing the course title, the frequency with which it is offered, and the enrollment statistics over the last five years, 1999-2003 (Q3). For the purposes of making this data more comprehensible, the researchers aggregated the data gathered in this section of the survey into the following categories:

- introductory survey;

- preservation management;

- digital preservation;

- photograph/audiovisual preservation;

- conservation ("hands-on" courses); and

- other "advanced topics" in preservation.

When it was not apparent into which category a class would fall, the investigators examined the course description on the institution's Web site, when available. The dividing line between introductory survey courses and more advanced management courses was the most difficult to draw; in cases where the research team was unsure, they erred on the side of coding it as an introductory course. Table 1 summarizes the frequency with which preservation courses are offered in LIS programs.

LIS master's programs focus primarily on offering a survey course once a year. Few schools give more advanced offerings in preservation, with several notable exceptions. Preservation management and digital preservation are the most likely candidates to be offered as advanced electives; photograph and audiovisual preservation courses are beginning to be offered in a small number of schools, while comparatively fewer schools offer conservation courses (defined as having a laboratory component). The small number of conservation courses may be related to a lack of available laboratory facilities at many LIS programs.

\section{Enrollment in Preservation Coursework}

Enrollment in LIS program preservation courses shows some growth in the last five years, particularly in the areas of introductory courses, digital preservation, and photographic and audiovisual preservation (see table 2). The encouraging upward trends in preservation enrollment must be seen in the light of the larger picture, which is the overall enrollment in MLIS programs over the same period. The Association of Library and Information Science Education (ALISE) reports that between 1999 and 2003, enrollment in MLIS programs rose significantly: from 11,241 in 1999 to 16,876 in $2003 .{ }^{37}$ Over a five-year period, MLIS enrollment increased 50 percent, while enrollment in basic preservation courses increased 66 percent, and the number of students in preservation management courses rose by 120 percent. Clearly, interest in preservation is keeping pace with the rise in the number of MLIS students.

Enrollment in electronic and audiovisual preservation courses shows steady increases over the five-year period, while the number of students enrolled in conservation has shown a small surge that was not maintained (the investigators interpret these numbers as essentially showing no real growth). Enrollment in other advanced preservation coursework (such as those focusing on technology, reformatting, and other current issues) has grown, but the number of courses and total number of students is so small that these data cannot be interpreted as an overall trend of the field.

Table 3 summarizes the number of preservation courses offered over the five-year period of 1999-2003 and gives the total number of students (both broken down by basic type of course). This table represents a different snapshot of the data, examining the average (mean) number of students enrolled in different courses. The average number of students enrolled in more advanced courses decreases significantly from the average of the introductory and management courses. Interestingly, only 7 schools offer a separate course in preservation management; however, the researchers suspect that many introductory preservation courses now emphasize a managerial approach and per-

Table 1. Frequency of preservation courses offered by LIS schools, by topic ( $N$ varies)

\begin{tabular}{lccccc}
\hline & Annually & Biannually & $\begin{array}{c}\text { More } \\
\text { than once } \\
\text { a year }\end{array}$ & $\begin{array}{c}\text { Irregular or } \\
\text { unspecified } \\
\text { frequency }\end{array}$ & $\begin{array}{c}\text { Total } \\
\text { number of } \\
\text { schools }\end{array}$ \\
Introductory survey & 17 & 5 & 2 & 3 & 27 \\
Preservation management & 4 & 1 & 2 & 0 & 7 \\
Digital preservation & 5 & 0 & 0 & 2 & 7 \\
Photograph audiovisual preservation & 4 & 0 & 3 & 0 & 5 \\
Conservation ("hands-on" courses) & 0 & 0 & 1 & 0 & 3 \\
Advanced topics in preservation & 2 & 0 & & 0 & 3
\end{tabular}

Note: Data represent number of schools offering a type of preservation course with a particular frequency. 
spective. The mean number of students enrolled in conservation is quite low; the intensive hands-on nature of most conservation courses requires a small student-to-teacher ratio and is not a cause for concern.

Digital preservation enrollment shows a promising increase over the five-year period, indicating that interest in this area is developing quickly, yet fewer than 1 percent of all MLIS students have had in-depth exposure to critical issues of digital preservation. The investigators consider the paucity of course offerings in digital preservation as a source of concern for all MLIS programs. The field will need students to have a basic grounding in this area as they build and administer digital libraries and recordkeeping systems.

\section{Preservation Specializations and Job Placement}

Only 5 schools report offering a separate specialization in preservation management (Q4). These figures include only students focusing on preservation administration, not conservation training (which is a separate track and requires significantly more background in paper chemistry and materials science, and additional training in repair, binding, and treatments). Over the past five years, 42 students have graduated with specializations in this area (Q5).
Table 2. Enrollment statistics in preservation courses, 1999-2003 (broken down by year, N varies)

Total

$\begin{array}{llllll}1999 & 2000 \quad 2001 & 2002 & 2003 & (1999-2003)\end{array}$

$\begin{array}{rrrrrr}300 & 404 & 366 & 422 & 502 & 1,994 \\ 87 & 137 & 117 & 195 & 192 & 728 \\ 52 & 85 & 90 & 88 & 134 & 449 \\ 0 & 17 & 39 & 23 & 79 & 158 \\ 62 & 82 & 98 & 67 & 72 & 381 \\ 6 & 6 & 17 & 34 & 45 & 108 \\ \mathbf{5 0 7} & \mathbf{7 3 1} & \mathbf{7 2 7} & \mathbf{8 2 9} & \mathbf{1 , 0 2 4} & \mathbf{3 , 8 1 8}\end{array}$

In the past two years, the number of such students has grown significantly_doubling in 2002-2003, and tripling in 2003-2004 - due to the revitalization of the preservation management program at one LIS program, and an increase in interest at other schools. Similarly, the investigators found that there were few opportunities for postgraduate certificates of advanced study in preservation; only 4 schools presently offer this opportunity, overlapping with the schools that offer MLIS study (CAS) in preservation. The number of students completing a CAS has been small—29 students over the last five years, with 1 school graduating 18 of those 29 certificate recipients (Q8, Q9). This data suggests that preservation is still seen largely as a niche to be filled by a few schools, rather than a specialization of wide appeal to all MLIS programs.

Table 3. Number of preservation course offerings, 1999-2003 ( $N$ varies)

\begin{tabular}{|c|c|c|c|}
\hline Type of course & $\begin{array}{l}\text { Total no. of courses } \\
\text { offered, 1999-2003 }\end{array}$ & $\begin{array}{l}\text { Total no. of students } \\
\text { enrolled, 1999-2003 }\end{array}$ & $\begin{array}{l}\text { Mean no. of students } \\
\text { per course }\end{array}$ \\
\hline Introductory courses $(N=27)$ & 81 & 1,994 & 24.6 \\
\hline Preservation management $(N=7)$ & 27 & 728 & 27.0 \\
\hline Digital preservation $(N=7)$ & 22 & 449 & 20.4 \\
\hline $\begin{array}{l}\text { Photograph/audiovisual preservation } \\
(N=5)\end{array}$ & 10 & 158 & 15.8 \\
\hline $\begin{array}{l}\text { Conservation (hands-on courses) } \\
(N=3)\end{array}$ & 56 & 381 & 6.8 \\
\hline Advanced topics in preservation $(N=3)$ & 10 & 108 & 10.8 \\
\hline Total & 164 & 3,818 & 23.3 \\
\hline
\end{tabular}


Comparing this data to information about job placement-for example, how many of these graduates were placed in positions where their primary responsibility was in the area of preservation-would be interesting. Unfortunately, many survey respondents indicated that such data have not been collected at their schools, thus the researchers are unable to determine how successful graduates have been in securing jobs in preservation management (Q30, Q31).

Despite the small number of opportunities for specializing in preservation, the study found that preservation is a key component of other areas of study. Nineteen (59.4 percent) of 32 schools responding to the question, "Is preservation a required or recommended course for particular tracks or specializations (other than conservation or preservation)?" indicated that preservation was either required or

Archives and records management is the specialization most likely to require or recommend preservation $(8$ schools require preservation and 4 schools recommend it for their archives curriculum) (Q7). Preservation also was cited as a required or recommended course for specializations in academic libraries (1 school recommends it), digital libraries (2 schools require it), and rare books and special collections (2 schools recommend it). Because preservation impacts the work of almost every department in a library or archive, many schools recommend that students have some basic familiarity with preservation concepts. Students often do not realize the full importance of preservation knowledge until they are working in the field. Thus, many MLIS graduates seek out continuing education opportunities in preservation after entering the workforce. recommended (Q6) (see table 4).

\section{Faculty Resources}

Preservation courses are taught mostly by part-time faculty drawn from the ranks of the profession; i.e., preservation administrators and conservators who work in a local institution (most often within the library system of the university). Eighteen faculty (27.7 percent) teach full-time as tenuretrack or tenured professors, 5 faculty $(7.7$ percent) teach full-time on a contract basis as nontenured lecturers, while the remaining two-thirds of the preservation faculty (64.6 percent) consists of professionals teaching as adjuncts rather than full-time faculty members (Q17). The number of full-time, tenure-track faculty who teach preservation is somewhat misleading, as many who teach in this area also are responsible for other areas, such as archives, special collections, and technical services. One must conjecture that the number of faculty who consider preservation to be their primary teaching and research area is smaller than the reported 18. When asked, "Are your preservation courses usually taught by full-time or part-time (adjunct) faculty?" one can see that the reliance on part-time faculty is even more pronounced (Q16):

- five schools use full-time faculty exclusively (15.6 percent);

- twenty schools use part-time faculty exclusively (62.5 percent); and

- seven schools use a combination of full- and part-time faculty (21.9 percent).

The investigators see a connection between the number of full-time faculty members whose specialty is preservation and the number of schools that offer a specialization in preservation. The small number of preservation faculty directly correlates to the availability of preservation specializations, as part-time instructors are rarely given the oppor-

Table 4. Specializations that require or recommend preservation

\begin{tabular}{|c|c|c|c|c|}
\hline Type of specialization & $\begin{array}{l}\text { No. of schools } \\
\text { requiring } \\
\text { preservation }\end{array}$ & $\begin{array}{l}\text { No. of schools } \\
\text { recommending } \\
\text { preservation }\end{array}$ & $\begin{array}{l}\text { No. of schools not } \\
\text { specifying required } \\
\text { or recommended }\end{array}$ & Total \\
\hline Academic libraries & 0 & 1 & 0 & 1 \\
\hline $\begin{array}{l}\text { Archival Studies degree/ } \\
\text { certificate programs }\end{array}$ & 4 & 1 & 1 & 6 \\
\hline $\begin{array}{l}\text { Archival Studies } \\
\text { specializations }\end{array}$ & 4 & 3 & 1 & 8 \\
\hline $\begin{array}{l}\text { Digital libraries/ } \\
\text { electronic information }\end{array}$ & 2 & 0 & 0 & 2 \\
\hline $\begin{array}{l}\text { MLIS degree programs } \\
\text { (when school offers } \\
\text { multiple information- } \\
\text { related degrees) }\end{array}$ & 0 & 2 & 0 & 2 \\
\hline $\begin{array}{l}\text { Rare books/special } \\
\text { collections }\end{array}$ & 0 & 2 & 0 & 2 \\
\hline Total & 10 & 9 & 2 & 21 \\
\hline
\end{tabular}
tunity to develop tracks within a curriculum.

Preservation instructors are most likely to have a master's degree in LIS or a related field (Q18). Thirty-eight faculty members hold a master's degree, 13 obtained certificates of advanced study in preservation administration or conservation, 23 earned Ph.D.'s, and 3 list other degrees or credentials (such as certified archivist or certification in hand bookbinding). Most instructors 
of preservation courses are part-time instructors drawn from the profession; that they are most likely to have professional credentials rather than research credentials is not surprising.

Only 5 schools out of 41 surveyed (12.2 percent) reported that they had firm plans to hire additional faculty in the area of preservation (Q19). All 5 respondents indicated that they would like to hire full-time, tenure-track faculty. Other choices were: full-time, non-tenure-track (lecturer or instructor), or part-time (adjunct) instructor (Q20). The other 36 schools that indicated that they had no immediate plans to make a hire in preservation chose the following reasons (some respondents chose more than one response) (Q21):

- meeting preservation needs at this time with current staffing (16 schools, 44.4 percent);

- preservation is not a strength of this program (8 schools, 22.2 percent); or

- fiscal resources do not allow a hire (10 schools, 27.8 percent).

Those indicating "other reasons" (7 schools, 19.4 percent) explained their responses in the following ways:

- "We are looking at adding a course eventually using faculty now in place."

- "We would like to hire another archives-related faculty who may have preservation expertise-but that wouldn’t necessarily be a priority."

- "Another program in the city and yet another in the state cover this-we're too small to repeat their work."

- "The enrollment figures have increased considerably in the last three years. We are looking at increasing the resources in the area of archives in general."

- "We are redesigning our archives/records management and preservation courses and don't know yet whether we will be adding faculty."

The data suggest that most LIS programs are not placing preservation as a high priority or are unwilling to make a firm commitment to this area at this time. The investigators see an interesting parallel between the preservation area and the archives specialty, in terms of the reluctance to commit new resources to growing these areas. ${ }^{38}$ While much of this hesitancy may be related to genuine concern over lack of resources, they also recognize the possibility that tracks in digital libraries and information technology are seen by many schools to be of the highest priority (particularly those aforementioned schools that have rechristened themselves as "I-schools").

\section{The Preservation Curriculum}

The survey asked respondents to indicate the content of their preservation courses by putting an " $\mathrm{x}$ " next to each topic listed on the survey (they also could write in topics not listed) (Q10) (see table 5). The investigators found that most preservation courses are very ambitious in scope, as evidenced by the high number of affirmative responses to each topic. Other topics mentioned included preservation research; preservation strategies; security; and insurance coverage, risk management, and liability. Other formats mentioned included "electronic media preservation," museum objects, and "clay tablets, papyri, vellum, etc."

Because of concerns about the survey's length, the investigators did not ask respondents to indicate the depth of treatment afforded each topic. The data suggest that faculty continue to add topics in their courses in response to the increasing number of formats for which librarians and archivists are responsible. A comparison of this list of topics to the one compiled by Cloonan in 1994 shows that current preservation courses cover much more ground than those of just a decade ago. ${ }^{39}$ While Cloonan's list does not mention specific formats, the assumption that preservation administrators would be dealing primarily with paper-based media is evident in many of the topics, which mention such activities as "library binding and contracting for services," "flattening paper," and "deciphering faded documents." Electronic media are not objects needing preservation, but are seen as potential tools for reformatting. The preservation course of today can no longer assume that students will be working in a book-and-paper world, and its syllabus has swelled to contain these new media.

Educators have cause for concern over how much time can be spent on each topic-one could assume that some topics are only given cursory attention, whereas others are explored in more depth. A 2005 study by Bastian and Yakel provides information on how much time is spent on different topics. $^{41}$

Preservation has been integrated into a number of other courses in LIS programs. Instructors teaching archives and manuscripts, collection development, or records management were most likely to have integrated preservation topics into their syllabi (Q11) (see table 6). Other courses mentioned as including preservation topics were management, "information in society," government information resources, organization of information, individual study, and film studies courses. Only one-third of LIS schools responding to this question indicated that they integrate preservation into their foundational course, while three-quarters of archives and manuscript course offerings and one-half of collection management courses do so. These figures reinforce the trend discussed in the review of the literature, which indicates that archival educators are more likely to emphasize the importance of preservation in archival courses than other LIS educators in other parts of the LIS curriculum.

The survey asked respondents to list related courses that include preservation as a significant component (defined as 
Table 5. Topics covered in preservation courses $(N=32)$

\begin{tabular}{|c|c|c|c|c|}
\hline \multirow[b]{2}{*}{ Topic or Format Covered? } & \multicolumn{2}{|c|}{ Yes } & \multicolumn{2}{|c|}{ No } \\
\hline & No. & $\%$ & No. & $\%$ \\
\hline $\begin{array}{l}\text { History and theory of conservation } \\
\text { and preservation }\end{array}$ & 30 & 93.8 & 2 & 6.3 \\
\hline Ethics of conservation and preservation & 28 & 87.5 & 4 & 12.5 \\
\hline $\begin{array}{l}\text { Conservation science } \\
\text { (including materials deterioration) }\end{array}$ & 26 & 81.3 & 6 & 18.8 \\
\hline $\begin{array}{l}\text { Book repair and rebinding } \\
\text { (including hands-on practice) }\end{array}$ & 22 & 68.8 & 10 & 31.3 \\
\hline Conservation treatments & 29 & 90.6 & 3 & 9.4 \\
\hline Enclosures and housing & 28 & 87.5 & 4 & 12.5 \\
\hline $\begin{array}{l}\text { Reformatting options } \\
\text { (microfilming, photocopying, digitization) }\end{array}$ & 29 & 90.6 & 3 & 9.4 \\
\hline $\begin{array}{l}\text { Control of environmental conditions } \\
\text { (temperature, relative humidity, air } \\
\text { quality, pest management) }\end{array}$ & 30 & 93.8 & 2 & 6.3 \\
\hline $\begin{array}{l}\text { Preservation assessment (surveying and } \\
\text { policy recommendations) }\end{array}$ & 29 & 90.6 & 3 & 9.4 \\
\hline Management (personnel, fiscal, facilities) & 27 & 84.4 & 5 & 15.6 \\
\hline $\begin{array}{l}\text { Emergency preparedness } \\
\text { and disaster recovery }\end{array}$ & 30 & 93.8 & 2 & 6.3 \\
\hline Staff and user education & 25 & 78.1 & 7 & 21.9 \\
\hline Other topics & 3 & 9.4 & 29 & 90.6 \\
\hline $\begin{array}{l}\text { Paper-based media } \\
\text { (books and documents) }\end{array}$ & 32 & 100.0 & 0 & 0.0 \\
\hline Photographic media & 29 & 90.6 & 3 & 9.4 \\
\hline $\begin{array}{l}\text { Audiovisual media (sound recordings } \\
\text { and moving images) }\end{array}$ & 27 & 84.4 & 5 & 15.6 \\
\hline $\begin{array}{l}\text { Magnetic and optical media (removable } \\
\text { storage media) }\end{array}$ & 24 & 75.0 & 8 & 25.0 \\
\hline Electronic records & 26 & 81.3 & 6 & 18.8 \\
\hline $\begin{array}{l}\text { Digital library objects (both digitized } \\
\text { and "born digital") }\end{array}$ & 23 & 71.9 & 9 & 28.1 \\
\hline Other formats & 2 & 6.3 & 30 & 93.8 \\
\hline
\end{tabular}

data that were obtained for this question are interesting, only a small number of schools chose to answer this question. The insufficient number of responses makes drawing conclusions difficult.

The survey also asked about the availability of related courses in other schools and departments of the university that may pertain to preservation or conservation studies (Q13) (see table 8). Out of 32 responses, 9 schools (28.1 percent) responded "yes," 21 schools (65.6 percent) responded "no" or left the question unanswered, and 2 schools (6.3 percent) indicated that they were "not sure." The 9 schools that responded affirmatively provided course titles, which have been summarized into disciplinary areas. The investigators find the results of this question to be of particular interest, as several schools apparently do not acknowledge the existence of other preservation-related courses outside of their school's offering. Yet, many larger universities do, in fact, offer related coursework, which faculty may discover if they do a bit of research into the university's course catalog to determine the presence of these other opportunities. Unfortunately, the potential for building preservation specializations using resources of other departments remains largely untapped at this time.

Six schools (19.4 percent) out of 31 respondents reported offering continuing education courses in preservation to working professionals in the field (Q14). Table 9 summarizes the topics cited by respondents (Q15). Given the data gathered by this survey, most LIS schools are not sources for continuing education in preservation at this time. Anecdotal evidence suggests that many continuing education workshops offered through universities have been either heavily reliant on grant funding or must be sustained through enrollment fees, which may partially explain why few universities regularly offer continuing education opportunities in this area.

Out of 41 responses to the question,

spending at least 10 percent of class time discussing preservation issues) and estimate the percentage of time spent on preservation (Q12). Sixteen schools out of 32 respondents (50 percent) reported that they had courses with significant preservation content. The information has been summarized using the categories shown in table 7 . Although the
"Do students have the opportunity to earn course credits for completing an internship or field placement in preservation work?" 32 schools (78 percent) indicated in the affirmative (Q25). For LIS programs that offer a specialization in preservation, all 5 require practical experience through 
internships or fieldwork (Q26). The investigators see this requirement as an indication that, in the field of preservation, practical experience is seen as being a necessary prerequisite for obtaining an entry-level position.

Thirty-two (78 percent) out of 41 schools report that their university's library system offers internship opportunities (Q27). Departments that often host interns include the following: archives (11; 34.4 percent); rare books and special collections (13; 40.6 percent); digitization and digital libraries (3; 9.4 percent); preservation, conservation, and book repair (10; 31.3 percent); reference (1; 3.1 percent); remote storage facility $(1 ; 3.1$ percent); technical services (4; 12.5 percent); and no department specified (13; 40.6 percent). The investigators suspect that a number of the respondents misinterpreted this question to apply to all students and internship sites, rather than those focused specifically on preservation work (hence the reporting of the reference department and the large number of respondents who did not indicate a particular department). Thus, the investigators are reluctant to draw any conclusions from this data other than to note that archives, special collections, and preservation departments are the most likely sites to welcome preservation students.

From the data collected, the researchers surmise that internships are widely available outside the university library system. Forty-one schools responded to the question, "What type of sites (external to the institution) host preservation interns?" (Q28). Responses include: libraries (30; 73.2 percent); archives $(32 ; 78$ percent); museums (17; 41.5 percent); historical societies (15; 36.6 percent); commercial vendors ( 3 ; 7.3 percent), and other sites ( 3 ; 7.3 percent). Under the "other" category, respondents listed "Combination archives/museum,"

Table 6. Preservation integrated into other courses? $(N=32)$

Schools integrating
preservation into course

\section{Other courses}

Introduction to librarianship/information studies core course

Archives and manuscripts

Rare books librarianship

Map librarianship

Special collections

Collections management/development

Digital libraries

Records management (including

electronic records management)

Technical services (including serials)

Other

$\begin{array}{rr}\text { No. } & \% \\ 10 & 31.3 \\ 24 & 75.0 \\ 9 & 28.1 \\ 1 & 3.1 \\ 10 & 31.3 \\ 16 & 50.0 \\ 14 & 43.8 \\ 17 & 53.1 \\ 5 & 15.6 \\ 3 & 9.4\end{array}$

Table 7. Related courses that incorporate preservation topics ( $N$ varies)

\begin{tabular}{lcr}
\hline Type of course & $\begin{array}{c}\text { No. of schools reporting } \\
\text { preservation as part } \\
\text { of related coursework }\end{array}$ & $\begin{array}{c}\text { Average \% } \\
\text { (mean) spen } \\
\text { preservation }\end{array}$ \\
Foundations of librarianship/ & 2 & 16.0 \\
information studies & 11 & 14.2 \\
Archives and records management & 3 & 21.7 \\
Electronic records management & 3 & 11.7 \\
Rare books/special collections & 3 & 10.7 \\
Technical services & 1 & 10.0 \\
Collection development & 2 & 10.0 \\
Digital libraries & 1 & 15.0 \\
Other coursework & & \\
(doctoral-level seminar) & &
\end{tabular}

Table 8. Preservation-related courses in other schools and departments ( $N$ varies)

\section{Department}

Art history/art conservation

Anthropology

Bookbinding

Cultural studies/ethnic studies

Human ecology (including textile conservation)

Museum studies

Multimedia production

Art history/art conservation

Anthropology

Bookbinding
Number of Schools Reporting Courses

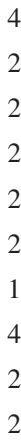

2

2

2

2

2

2 
Table 9. Continuing education courses in preservation offered through LIS programs $(N=6)$

\begin{tabular}{lclc}
\hline Course topics & $\begin{array}{c}\text { No. of schools } \\
\text { offering topic }\end{array}$ & \multicolumn{1}{c}{$\begin{array}{c}\text { Frequency } \\
\text { More than once a year }\end{array}$} & $\begin{array}{c}\text { Enrollment in courses on } \\
\text { this topic, 1999-2003 }\end{array}$ \\
Book history & 1 & $\begin{array}{l}\text { More than once a year } \\
\text { More than once a year (2 } \\
\text { schools); Not specified (1) }\end{array}$ & $55^{1}$ \\
Conservation/book repair & 1 & Not specified & $50^{2}$ \\
Digitization and digital libraries & 3 & Every other year & 161 \\
Disaster planning & 3 & Not specified & $65^{3}$ \\
Electronic records & 1 & Not specified & $25^{4}$ \\
Library facilities & 1 & $33^{5}$ \\
Preservation management & 1 & Every other year & $29^{6}$
\end{tabular}

1. Missing 2003 figures.

2. 2003 figures only.

3. Figures for 2001, 2002, and 2003 only.

4. Figures for 2000 and 2002 only.

5. Figures for 2000 and 2002 only.

6. Figures for 2000 and 2003 only.

7. Figures for 1999, 2001, and 2003 only.

a local public television station, and corporate libraries and archives. Apparently, many LIS programs encourage students interested in preservation to continue their education through an internship; most schools offer little in the way of advanced electives in this area. While the importance of learning skills and techniques in a practitioner environment is undeniable, practical skills must be balanced with a more theoretical orientation to the profession. Internships alone cannot provide this professional knowledge.

Internships and fieldwork are largely unpaid. Out of 40 responses to a question about the percentage of internship sites that offer remuneration, 29 reported that none of the sites offered financial compensation (Q29). Two schools reported that 100 percent of their internship sites offer wages to students, with the other 9 schools reporting anywhere from 1 percent to 95 percent. The responses are unclear if respondents refer specifically to preservation internship sites or to all internship sites. Thus, the investigators are unable to draw any conclusions about the existence of compensated preservation internships.

Thirteen schools out of 41 surveyed (31.7 percent) indicated a desire to enhance their current curriculum with additional offerings in the area of preservation (Q22). Subjects seen as potential new courses include (respondents could mark more than one choice):

- introductory course in preservation history $(3 ; 27.3$ percent);

- collections conservation laboratory (3; 27.3 percent);
- reformatting $(4 ; 36.4$ percent);

- fieldwork or internships (4; 36.4 percent);

- photographic media (1; 9.1 percent);

- digital preservation (6;54.5 percent); and

- other courses $(4 ; 36.4$ percent).

Other courses mentioned included "Practicum work full-time in our conservation lab," preservation ethics, and management of cultural heritage collections. Reformatting and digital preservation seemed to generate the most interest, which is unsurprising given the current focus on building digital libraries both in the profession and as a growing trend in LIS education. Although the survey asked respondents to indicate the year that they planned on offering such courses, few respondents did so, thus the investigators are unable to report results on that part of the question.

The other 28 schools (68.3 percent) showed no interest in adding additional coursework in the area of preservation (Q24). The reasons cited for not offering additional courses included the following (some respondents chose more than one response):

- preservation discussed sufficiently in other courses (15; 53.6 percent);

- lack of perceived interest by students $(2 ; 7.1$ percent);

- lack of available expertise of current faculty (5; 17.9 percent); and

- lack of fiscal resources (10; 35.7 percent). 
Other reasons ( $3 ; 10.7$ percent):

- "We are federated with a program that covers thisno need to duplicate."

- "We plan to move slowly, will be looking at a digitization course, but may not be ready to add it in 1-3 years."

Many schools feel that preservation is already sufficiently covered by current course offerings, while a lack of fiscal resources is the other main limitation. The lack of available expertise may be closely related to the lack of fiscal resources, as well. The investigators find the "already sufficiently discussed" reasoning to be curious, considering the high number of LIS schools that currently lack advanced electives in areas of need such as digital preservation.

\section{Conclusion}

Data from this study reveal tantalizing pieces of the preservation education landscape. While investigators noticed several potentially encouraging trends, such as continued interest in preservation through steadily increasing enrollment figures, other data show that institutions, particularly in higher education, are not ready to make a commitment of resources (through new courses or faculty hires) to grow preservation beyond its current coverage in library schools. The authors suspect that continuing education is picking up much of the slack that LIS programs are creating, offering programs on multiple topics not given sufficient coverage at the graduate level. Preservation education in the areas of electronic resources, visual materials, and audiovisual resources appears to be in short supply at the graduate level.

The investigators found that the data generated from this study answered many of the questions raised about the who, what, when, and where of preservation education, but did not sufficiently capture the underlying explanations of certain phenomena. For example, why has the increased scope of preservation in the last decade not resulted in significantly increased course offerings and additional faculty resources? Why is preservation still not considered to be a core knowledge area by many LIS schools? Why has the development of preservation education stalled at the level of establishing basic professional skills and competencies, while not addressing the need to develop a theoretical foundation to support research and scholarly agendas, which would sustain the field over the long term?

The investigators feel that these sorts of questions are best addressed using another methodological approach, ideally a qualitative one. Thus this study represents the first phase of a larger research project. Building upon the initial results of the survey, the investigators plan to follow up with in-depth interviews of key informants involved in preservation education at selected sites. After analyzing the interview data and comparing those results to those of the survey, the investigators hope to have a more complete picture of the state of preservation education in North America, which will be used to create recommendations for directing preservation education in the next decade.

\section{References and Notes}

1. Michèle V. Cloonan, Global Perspectives on Preservation Education (Munich: Saur, 1994), 5.

2. Deanna B. Marcum, "Preservation Education," in Advances in Preservation and Access, vol. 1, ed. Barbra Buckner Higginbotham and Mary E. Jackson (Westport, Conn.: Meckler, 1992), 116.

3. North East Document Conservation Center, www.nedcc.org (accessed May 29, 2006).

4. Stephen G. Nichols and Abby Smith, The Evidence in Hand: Report of the Task Force on the Artifact in Library Collections (Washington, D.C.: Council on Library and Information Resources, 2001).

5. Abby Smith, David Randal Allen, and Karen Allen, Survey of the State of Audio Collections in Academic Libraries (Washington, D.C.: Council on Library and Information Resources, 2004), 31.

6. Nichols and Smith, The Evidence in Hand.

7. Michèle V. Cloonan, "W(h)ither Preservation?" Library Quarterly 71, no. 2 (2001): 231-42.

8. Ibid., 232

9. D. W. G. Clements et al., Review of Training Needs in Preservation and Conservation (Paris: UNESCO, 1989), 19.

10. Frederick J. Stielow, "New Archival and Preservation Scholarship: Communication and Literature in Transition: A Review Article," Library Quarterly 63, no. 1 (1993): 93.

11. James Turner, "Training for Audiovisual Archivists and Librarians," IFLA Journal 17, no. 3 (1991): 248-55; Hilary A. Kaplan and Brenda S. Banks, "Archival Preservation: The Teaming of the Crew," American Archivist 53, no. 2 (1990): 266-73.

12. Kaplan and Banks, "Archival Preservation," 269.

13. Paul Conway, "Archival Preservation: Definitions for Improving Education and Training," Restaurator 10, no. 2 (1989): 48.

14. Helen P. Harrison, "Training for Audiovisual Archivists," Audiovisual Librarian 16, no. 3 (1990): 116-22; Ray Edmondson, Audiovisual Archiving: Philosophy and Principles (Paris: UNESCO, 2004), 11-12.

15. Turner, "Training for Audiovisual Archivists and Librarians."

16. Redefining Film Preservation: A National Plan: Recommendations to the Librarian of Congress in Consultation with the National Film Preservation Board, coordinated by Annette Melville and Scott Simmon (Washington, D.C.: Library of Congress, 1994).

17. Folk Heritage Collections in Crisis (Washington, D.C.: Council on Library and Information Resources, 2001), 51, 53; Smith, Allen, and Allen, Survey of the State of Audio Collections, 23. 
18. Graham Matthews and Stella Thebridge, "Preservation Management Training and Education: Developing a Sectorwide Approach," New Library World 102, no. 1170/1171 (2001): 443-51.

19. Deanna B. Marcum, "Research Questions for the Digital Era Library," Library Trends 51, no. 4 (2003): 636-51.

20. John Feather, Guidelines for the Teaching of Preservation to Librarians, Archivists, and Documentalists from a Joint Working Party of IFLA's Sections on Conservation and Education and Training, IFLA Professional Reports No. 18 (Paris: IFLA, 1990), 5,

21. Jennifer A. Younger, "An Employer's Perspective on LIS Education," Technical Services Quarterly 15, no. 1/2 (1997): 109-18.

22. Feather, Guidelines for the Teaching of Preservation, 5.

23. Jonathan Rhys-Lewis, "A Current View of Education and Training in Archive Conservation," Journal of the Society of Archivists 18, no. 2 (1997): 175-80.

24. Michèle Valerie Cloonan, "Preservation without Borders," Libri 47, no. 3 (1997): 180-86.

25. Michèle Valerie Cloonan, Global Perspectives on Preservation Education (Munich: Saur, 1994), 26.

26. Cloonan, "W(h)ither Preservation?"

27. Association of Research Libraries Preservation of Research Library Materials Committee, Recognizing Digitization As a Reformatting Method (Washington, D.C.: ARL, 2004), www .arl.org/preserv/digit_final.html (accessed Jan. 31, 2005).

28. Sheila A. McAlister and Gregor Trinkaus-Randall, "Wouldn't Be Prudent': Digitization As a Preservation Reformatting Method," Microform \& Imaging Review 33, no. 4 (2004): 181-83; "Digitization As a Preservation Method_Comments from the Netherlands," Microfilm and Imaging Review 33, no. 4 (2004): 191-94; Andrew Hart, "A Critique of "Recognizing Digitization As a Preservation Reformatting Method," Microform \& Imaging Review 33, no. 4 (2004): 184-87; David Adams et al., "Addressing a Risk Perspective when Considering Digitization As a Preservation Reformatting Method: A Response from 'Down Under," Microform \& Imaging Review 33, no. 4 (2004): 188-89.

29. Jacob Nadal, "It's Time to Recognize the Technologies That Are In Place," Microform \& Imaging Review 33, no. 4 (2004): 198.
30. Ellen Cunningham-Kruppa, "Digitization for Preservation: Far Too Many Benefits Over Microfilming," Microfilm \& Imaging Review 33, no. 4 (2004): 201-03; Jan Merrill-Oldham and Stephen Chapman, "Why the Preservation Community Should Support ARL's Call for Acceptance of Digitization As a Preservation Reformatting Method," Microfilm \& Imaging Review 3, no. 4 (2004): 204-06.

31. Association of Research Libraries, Recognizing Digitization.

32. A list of ALA-accredited graduate programs may be found at www.ala.org/ala/accreditation/lisdirb/lisdirectory.htm (accessed Sept. 22, 2003).

33. Jean Ann Croft, online posting, "Study on Preservation Education," PADG mailing list, Sept. 23, 2003, http:// palimpsest.stanford.edu/byform/mailing-lists/padg/2003/09/ msg00018.html (accessed May 29, 2006); Karen F. Gracy, online posting, "Seeking Participants in Study of Preservation Education," Sept. 22, 2003, http://listserv.utk.edu/cgi-bin/ wa?A2=ind0309\&L=jesse\&P=R7807\&I=-3 (accessed May 29, 2006); Karen F. Gracy, "Re: Seeking Participants in Study of Preservation Education," e-mail to Forum for Archival Educators mailing list, Sept. 22, 2003.

34. Preservation Education Needs for the Next Generation of Information Professionals: A Study Funded by the University of Pittsburgh Central Research Development Program, www .sis.pitt.edu/ kgracy/Pres_Edu_Study.htm (accessed May 29, 2006).

35. "Study on Preservation Education," Abbey Newsletter 26, no. 6 (2003): 97.

36. Cloonan, Global Perspectives, 5 .

37. Data taken from the 2000, 2001, 2002, 2003, and 2004 editions of the Library and Information Science Education Statistical Report (Table II-1-a-1), http://ils.unc.edu/ALISE (accessed May 29, 2006).

38. For data on future plans for hiring archival studies faculty, see Richard J. Cox et al., "Archival Education in North American Library and Information Science Schools," Library Quarterly 71, no. 2 (2001): 161-62.

39. Cloonan, Global Perspectives, 87.

40. Ibid., 87.

41. Jeannette Bastian and Elizabeth Yakel, “Are We There Yet?': Professionalism and the Development of an Archival Core Curriculum in the United States," Journal of Education for Library and Information Science 46, no. 2 (2005): 95-114. 


\section{Appendix: Survey Instrument}

\section{Preservation Education Needs for the Next Generation of Information Professionals Survey for Educators Teaching Preservation Coursework for College and University Degree Programs}

\section{Types of Courses/Frequency Offered}

1. Does your institution offer coursework on preservation and/or conservation of library/ archival materials?

Yes (go to next question)

No (go to question 19)

2. How many courses do you offer on preservation of library/archival materials? Do not include courses that merely incorporate preservation as part of a related topic (such as archives or collection development) unless preservation issues constitute at least onethird of the material covered.

1

2

3

More than 3

3. List each preservation course offered, and indicate the regularity with which it is offered. Also indicate its enrollment over the last five years, broken down by years. Attach additional sheets as necessary.

\begin{tabular}{|c|c|c|}
\hline Course Title & Frequency & $\begin{array}{l}\text { Enrollment over the } \\
\text { Last Five Years }\end{array}$ \\
\hline & & $\begin{array}{l}\text { 2003: } \\
\text { 2002: } \\
\text { 2001: } \\
\text { 2000: } \\
1999:\end{array}$ \\
\hline & & $\begin{array}{l}\text { 2003: } \\
\text { 2002: } \\
\text { 2001: } \\
\text { 2000: } \\
\text { 1999: }\end{array}$ \\
\hline & & $\begin{array}{l}\text { 2003: } \\
\text { 2002: } \\
\text { 2001: } \\
\text { 2000: } \\
\text { 1999: }\end{array}$ \\
\hline & & $\begin{array}{l}\text { 2003: } \\
\text { 2002: } \\
\text { 2001: } \\
\text { 2000: } \\
\text { 1999: }\end{array}$ \\
\hline & & $\begin{array}{l}\text { 2003: } \\
\text { 2002: } \\
\text { 2001: } \\
\text { 2000: } \\
\text { 1999: }\end{array}$ \\
\hline
\end{tabular}




\section{Preservation and Specializations}

4. Does your institution offer students a preservation track/specialization?

Yes (go to next question)

No (go to question 6)

5. If yes, how many students have elected to specialize in preservation in the last five years?

2003-2004 academic year:

2002-2003 academic year:

2001-2002 academic year:

2000-2001 academic year:

1999-2000 academic year:

6. Is preservation a required or recommended course for particular tracks or specializations

Yes (go to next question)

No (go to question 8)

7. If yes, please list specialization(s) where preservation coursework is recommended or required:

Required?
Required?
Required? $\_$Recommended?
Recommended?

8. Does your institution offer students a post-bachelor's or post-master's certificate in preservation?

Yes (go to next question)

No (go to question 10)

9. If yes, how many students have elected to obtain a certificate in preservation in the last five years?

2003:

2002 :

2001:

2000:

1999:

\section{Content of Preservation/Conservation Coursework}

10. What issues are covered in preservation coursework? Check all that apply.

History and theory of conservation/preservation

Ethics of conservation/preservation

Conservation science (including materials deterioration)

Topics:

Book repair and rebinding (including hands-on practice)

Conservation treatments

Enclosures and housing

Reformatting options (microfilming, photocopying, digitization)

Control of environmental conditions (temperature, relative humidity, air quality, pest management) 
Preservation assessment (surveying and policy recommendations)

Management (personnel, fiscal, facilities)

Emergency preparedness and disaster recovery

Staff and user education

Other:

Formats:

Paper-based media (books and documents)

Photographic media

Audiovisual media (sound recordings and moving images)

Magnetic and optical media (removable storage media)

Electronic records

Digital library objects (both digitized and "born digital")

Other:

\section{Related Coursework}

11. Into what other coursework do you incorporate preservation? Please check all that apply.

Introduction to librarianship/information studies core course

Archives and manuscripts

Rare books librarianship

Map librarianship

Special collections

Collections management/development

Digital libraries

Records management (including electronic records management)

Technical services (including serials)

Other:

12. Please list any related courses that include preservation as a significant component (defined as spending at least 10 percent of class time discussing preservation issues).

\begin{tabular}{|l|c|}
\hline Course Title & $\begin{array}{c}\text { Percentage of Course Devoted } \\
\text { to Preservation Issues }\end{array}$ \\
\hline & \\
\hline & \\
\hline & \\
\hline
\end{tabular}

13. Are there any courses in other departments of the university that relate to preservation or conservation (such as chemistry, engineering, anthropology, archaeology, art, art history, film studies, architecture). Please list any relevant courses below. 


\section{Continuing Education}

14. Do you offer any continuing education courses in preservation to working professionals in the field?

Yes (go to next question)

No (go to question 16)

15. Please list any continuing education courses offered in the area of preservation, and indicate the regularity with which they are offered. Also indicate enrollment over the last five years, broken down by years.

\begin{tabular}{|c|c|c|}
\hline Course Title & Frequency & $\begin{array}{c}\text { Enrollment over the } \\
\text { Last Five Years }\end{array}$ \\
\hline & & $\begin{array}{l}\text { 2003: } \\
\text { 2002: } \\
\text { 2001: } \\
\text { 2000: } \\
\text { 1999: }\end{array}$ \\
\hline & & $\begin{array}{l}\text { 2003: } \\
\text { 2002: } \\
\text { 2001: } \\
\text { 2000: } \\
\text { 1999: }\end{array}$ \\
\hline & & $\begin{array}{l}\text { 2003: } \\
\text { 2002: } \\
\text { 2001: } \\
\text { 2000: } \\
\text { 1999: }\end{array}$ \\
\hline & & $\begin{array}{l}\text { 2003: } \\
\text { 2002: } \\
\text { 2001: } \\
\text { 2000: } \\
\text { 1999: }\end{array}$ \\
\hline & & $\begin{array}{l}\text { 2003: } \\
\text { 2002: } \\
\text { 2001: } \\
\text { 2000: } \\
\text { 1999: }\end{array}$ \\
\hline
\end{tabular}

\section{Faculty Resources}

16. Are your preservation courses usually taught by full-time or part-time (adjunct) faculty? Full-time

Part-time (adjunct)

Combination of full-time and part-time faculty

17. Fill in the blanks with the number of instructors teaching in the area of preservation at your institution or organization. Do not include faculty who merely incorporate preservation as part of a related topic (such as archives or collection development).

Full-time, tenure-track/tenured (assistant, associate, or full professor)

Full-time, non-tenure-track (lecturer/instructor)

Adjunct (part-time) instructor

18. How many faculty members noted in question 17 hold:

(Note: The total number of degrees reported here may be greater than the total number of faculty reported in question 17). 
A professional-level master's degree?

A certificate of advanced study in conservation or preservation?

A Ph.D. degree?

Another degree or certification (please list types: ?

19. Do you have any plans to hire additional faculty in the area of preservation?

Yes (go to next question)

No (go to question 21)

20. If yes, what type of position would be offered?

Full-time, tenure-track/tenured position (assistant, associate, or full professor)

Full-time, non-tenure track position (lecturer/instructor)

Part-time instructor (adjunct)

Go to question 22.

21. If no, why not?

We are meeting our preservation education needs at this time with current staffing levels.

Preservation is not a "strength" of this program and we are not interesting in developing expertise in this area.

We would like to hire in the area of preservation, but fiscal resources do not allow a hire at this time.

Other:

\section{Future Plans for Curricula}

22. Does your institution plan to introduce new preservation coursework in the near future (1-3 years)?

Yes (go to next question)

No (go to question 24)

23. If yes, please indicate what type(s) of course(s) will be offered and when you hope to offer it (them):

\section{Year Type of Course}

Introductory course in preservation

Collections conservation laboratory (book repair, rebinding, deacidification, other treatments)

Reformatting (microfilming, copying, digitization)

Fieldwork/internship (placement in an archive, library, rare book collection, etc.)

Specialized preservation seminars in:

Photographic media

Visual materials (architectural drawings, maps, prints, etc.)

Audiovisual media (sound recordings, moving images)

Digital preservation (electronic records and other digital media)

Other:

Go to question 25.

24. If no, why not?

Preservation felt to be discussed sufficiently in core courses or elective courses on related topics (e.g., archives coursework) 
Lack of perceived interest by students

Lack of available expertise of current faculty

Lack of fiscal resources

Other:

\section{Fieldwork/Internship Opportunities}

25. Do students have the opportunity to earn course credits for completing an internship or field placement in preservation work?

Yes

No

26. (Answer only if your school has a preservation specialization.) Is practical experience (obtained through internships or fieldwork) required for the specialization in preservation? Yes No

27. Does your institution provide internship opportunities within its own library system? Yes (please list departments that host interns):

No

28. What types of sites (external to the institution) host preservation interns?

Libraries
Archives
Museums
Historical societies Commercial vendors Other:

29. Estimate the percentage of the internship sites provides some sort of remuneration (wage, stipend, etc.)?

\section{Postgraduate Employment}

30. Do you track students seeking employment in the area of conservation and/or preservation management?

Yes (go to next question) No (go to question 32)

31. If so, how many students of your program have been hired in preservation-related positions after graduation in the last five years (e.g., as preservation administrators)? 2003 2001 2000 1999 2002

\section{Future Participation in This Study of Preservation Education Needs}

32. May the investigators of this study contact you or a representative of your institution again about participating in the next phase of this study? Please check the appropriate box below with your preference and include contact information if requested.

No, I am not interested in further participation. Please do not contact me again.

Yes, I (or a representative of my institution) would be interested in further participation. Please contact address, phone number, and/or e-mail: at the following E-Mail:

Thank you for participating in this survey! Any further questions or comments may be directed to Dr. Karen F. Gracy (kgracy@pitt.edu) or Ms. Jean Ann Croft (jeanann@pitt.edu). 